\title{
Mimari Tasarım Eğitiminde Yaz Okulu Deneyimi: Öğrenci Performansı Üzerinden Bir Değerlendirme
}

\section{A Summer School Experience in Architectural Design Education: An Evaluation on Student Performance}

\section{Merve ÖZKAYNAK ${ }^{a,}{ }^{*}$,ilknur ACAR ATA ${ }^{b}$}

\author{
${ }^{a}$ Arş. Gör., Amasya Üniversitesi, Mimarlık Fakültesi, Mimarlık Bölümü, Amasya, 05240, Türkiye \\ ${ }^{\text {b} A r s ̧ . ~ G o ̈ r . ~ K o n y a ~ T e k n i k ~ U ̈ n i v e r s i t e s i, ~ M i m a r l ı k ~ v e ~ T a s a r ı m ~ F a k u ̈ l t e s i, ~ M i m a r l ı k ~ B o ̈ l u ̈ m u ̈, ~ K o n y a, ~ 42285, ~ T u ̈ r k i y e ~}$
}

Article history: Received 11-01-2019/ Accepted 11-07-2019

\section{ÖZET ABSTRACT}

Stüdyo eğitimi, proje yürütücüsünün danışmanlığında, öğrencilerin fikir ve tasarımlarının verilen program ve sürede projenin gelişimini sağlayarak dönem sonunda proje çıktılarının beklendiği eğitim sürecidir. Mimarlık eğitiminde tasarım bilgisinin aktarılmasından ziyade öğrencinin tasarım sürecini öğrenmesi hedeflenmektedir. Mimarlık eğitiminde normal öğretimden farklı olarak yaz okulu kısıtlı zamanda öğrencilerin kaldıkları dersleri, farklı üniversitelerde almalarına olanak tanıyan eğitim dönemidir.

Bu çalışmada Selçuk Üniversitesi yaz okulu kapsamında eş zamanlı olarak iki farklı stüdyoda, iki farklı ders yürütücüsü tarafından yürütülen ve aynı sürede, ortak proje alanı ve ortak ihtiyaç programı kapsamında proje 5 ve 6 öğrencilerinin katılımı ile atölye çalışması yapılmıştır. Çalışmanın amacı mimarlık eğitiminde kısıtı zaman içerisinde yürütülen yaz okulu döneminin sürecini, sınırlılıklarını ve planlanmasını değişkenleri ile ele almaktır. Sonuç olarak öğrencilerin devamlılık oranları ve proje çıktıları incelenerek, yaz okulunda yaşadıkları problemler ve bunlara yönelik üretilen çözümlere yer verilmiştir.

Anahtar Kelimeler:Mimarlık Eğitimi, Öğrenci

Performansı, Stüdyo Eğitimi, Yaz Okulu
Studio training is the training process in which students' ideas and designs are expected to be projected at the end of the term by providing the development of the project in the given program and time. It is aimed that the student learns the design process rather than transferring design knowledge in architectural education. Unlike normal education in architecture education, summer school is a period of education that allows students to take courses at different universities in limited time.

In this study, in the same period conducted by two different lecturers in two different studios simultaneously within the scope of Selçuk University Summer School, a workshop was held with the participation of 5 and 6 studio students within the scope of the common project area and common needs program. The aim of the study is to examine the process of summer school period in a limited time in architecture education, its limitations, planning and the difference of summer school from the normal period. As a result, the continuity ratios and project outcomes of the students were examined, the problems they experienced in summer school and the solutions produced for them were included.

Keywords:Architectural Educaiton, Student Performance, Studio Education, Summer School

\section{GİRIŞ}

Diğer birçok meslek eğitiminden farklı olan ve çeşitli tasarım araçları ile yöntemlerin kullanıldığı mimarlık eğitiminin asıl amacı tasarlama sürecinin öğretilmesidir. Zaman içerisinde çeşitli ekollerin ortaya çıktığı mimarlık eğitimi düşünme ve yorumlama gibi teorik öğretimin yanı sıra tasarlama ve deneyimleme sürecini kapsayan uygulamalı eğitimin ağırlıkta olduğu bir yapıya sahiptir. Tasarlama sürecinin öğrenciye aktarılarak, öğrenciyi mesleğe hazırlayan ve öğrencinin yürütücüden aldığı çeşitli kritikler ile tasarımını geliştirmesini sağlayan en önemli olgu mimarlık stüdyo dersleridir. Dutton (1987); tasarım stüdyosu için diğer derslerin müfredatına göre entegre etme ve mimari proje anlama becerisini geliştirmesinden dolayı mimarlık eğitiminin kalbi olduğunu ileri sürmektedir.

Tarihsel süreçte tasarım eğitimi bünyesinde gerçekleşen değişimlerden en çok etkilenen alanlar tasarım eğitiminin bel kemiğini oluşturan tasarım stüdyolarıdır. Tasarım stüdyoları günümüzdeki eğitim anlayışına ulaşana dek tarihsel süreçte birçok değişim geçirmiştir (Onur ve Zorlu, 2017). Mimarlık eğitim tarihinde üç dönüm noktası saptamak olasıdır. Bunlardan ilki, mimarlık okullarının olmadığı, mimarlık eğitiminin loncalar ve inşaat alanlarında yürütüldüğü dönemdir. İkinci dönüm noktası, mimarlık okullarının ortaya çıkmasıyla yaşanır. Ancak bu okullar bugünkülerden oldukça farklıdır. Bu dönemin temel özelliği, okulda yalnızca kuramsal eğitimin verilmesi, tasarım deneyinin okul dışında, mimarların atölyelerinde gerçekleşmesidir. Üçüncü dönem ise, uygulamanın okulla bütünleştiği ve stüdyonun mimarlık eğitimiyle birlikte kurumlaştığı dönemdir (Ciravoğlu, 2003).

* Corresponding author

E-mail address: merve.ozkaynak@hotmail.com http://dx.doi.org/10.16950/iujad.511970 Orcid: 
Üçüncü dönemde yaşanan değişimlerden biri olan Ecole des Beaux Arts eğitimi; klasik Yunan, Roma ve Rönesans mimarlığına dayalı "klasisizm" anlayışına sahiptir (Tok ve Ayyıldız Potur, 2016). 17. yüzyılda kurulan Fransız Kraliyet Akademisi'nin bir devamı olan ve mimarlık eğitiminde uzun süre egemenliğini sürdüren Ecole des Beaux Arts, modernist hareketin yaygınlaşmasıyla zayıflamış, 20. Yüzyılın ilk yarısında tasarım okullarındaki eğitim modelleri büyük ölçüde Bauhaus'tan etkilenmeye başlamıştır (Arıdağ, 2005).

Kuram ile uygulamayı birleştirmek ve uygulama ağırlıklı bir eğitim vermek isteyen Alman mimar Walter Gropius (Düzgün, 2004), 1919 yılında Weimar'daki Güzel Sanatlar Yüksek Okulu ile Saksonya Tatbiki Güzel Sanatlar Okulu'nu tek çatıda birleştirerek Bauhaus okulunu kurmuştur (Özer, 1964). Fakat 1933 yılında Naziler tarafından kapatılmasının ardından, dünyanın her yerine dağılan ve özellikle Amerika'ya göç ederek, mülteci entelektüeller-Hitler dönemi göçmenleri olarak adlandırılan akademisyenler tarafından, Bauhaus ilkeleri yeni kurulan okullarda yeniden inşa edilmiştir (Tok ve Ayyıldız Potur, 2016). Bauhaus'la birlikte öğrenci-öğretim elemanı (usta-çırak) etkileşiminin ve bu etkileşimle beraber öğretim yönteminin önem kazandığı görülmektedir. Bauhaus öğrencinin aktif bırakılarak özgürce gelişmesine olanak tanıyan, yaparak öğrenmesine ve kullanılan araçların temel özelliklerinin keşfederek kalıplardan arınmasına olanak tanıyan bir eğitim yöntemi olarak kullanılmıştır (Dikmen, 2011).

Dünya'da Ecole des Beaux Arts adını alan üslüp mimarlıkları eğitimi, Türkiye'de ise Sanayi-i Nefise Mekteb-i Alisi, sonra Devlet Güzel Sanatlar Akademisi, Ioncaların usta-çırak iliş̧isini benimsemiştir (Yürekli, 2014). Ülkemizdeki mimarlık eğitimi de bu gelişmelere koşut olarak gelişme göstermiş, usta-çırak ilişkisi biçiminde yürüyen öğrenme düzeni 1883 yılında Sanayii Nefise Mektebi (Mimar Sinan Üniversitesi MSÜ), 1942 yılında eğitime başlayan İstanbul Teknik Okulu (İstanbul Teknik Üniversitesi İTÜ), 1945 yılında Yıldız Teknik Üniversitesi (YTÜ) ve 1956 yılında da Orta Doğu Teknik Üniversitesi (ODTÜ) ile sürmüştür (Dikmen, 2011). Mimarlık eğitiminin strüktürel yapısının önce sanat (Ecoledes Beaux Arts) sonra bilgi (Orta Avrupa-Alman Ekolü) ve daha sonra da bilim (Anglo-Sakson Ekolü) şeklinde değiştiği görülmektedir. Bugün ise bilimselleşme ve uzmanlaşmanın getirdiği birbirinden kopuk ve mimarlığın bütünleşik yapısından uzak bir bilgi aktarımı modelinin yaygın olduğu gözlenmektedir. Mimarlık eğitiminde bugün ülke, kurum ve öğreticilere göre değişen geniş bir yaklaşım çeşitliliği gözlenmektedir (Nalçakan, 2006).

Günümüzde benimsenen farklı yaklaşımlara ve kullanılan yöntemlerin çeşitliliğine rağmen tasarım eğitimi belirli amaçlar doğrultusunda verilmektedir. Mimari tasarım stüdyolarının amaçları; öğrencinin edindiği bilgi ve beceri sentezinin ve uygulamalı entegrasyonun yapılması; tasarım probleminin çevresi içinde bir matematik problemi çözme mantığı ile çözüm bilincinin geliştirilmesi; öğrencinin dünya ile ilişkisinin güçlendirilmesi, düşünce geliştirme, karar verme süreçlerinin, yöntemlerinin, becerilerinin elde edilmesi ve en önemlisi tasarlama felsefe ve kuramına dayalı tasarlama becerilerinin geliştirilmesidir (Hacıhasanoğlu vd., 2003). Mimari tasarım stüdyosunda hedeflenen; tasarım bilgisinin doğrudan aktarılması değil, bilgiyi bir bağlam içerisine yerleştirilerek öğrencinin kendisinin keşfetmesine olanak sağlamaktır. Tasarım bilgisi ancak bu şekilde kazanılırsa kalıcı olabilir ve ileride karşılaşılacak olan durumlara adapte edilebilir (Şahin, 2013). Tasarım düşüncesinin bir dili olduğunu savunan Uluoğlu (1990) tasarım dilinin konuşma dilinde olduğu gibi, dili meydana getiren sözcüklerin ve bu sözcükleri bir araya getirmenin kuralları olduğunu ifade etmektedir. Bu noktada mimari tasarım eğitiminin amacı, tasarım dilinin öğretilmesidir (Uluoğlu, 1990).

Günümüzde çoğu mimari tasarım stüdyosu, karmaşık ve zorlu bir deneyim ortamlarıdır. Öğrencilerin sadece birçok yeni konsepti ve fikri kavraması beklenmez, aynı zamanda tasarım yapmak ve tasarım yapmayı öğrenmek başta olmak üzere en az iki görevi aynı anda yapmaları da istenmektedir. Buna ek olarak öğrenciler fikirlerini sunmalı ve savunmalı, eğitmenlerle ve diğer öğrencilerle kişisel ilişkiler kurmalı, yeni teknikler ve beceriler öğrenmelidir (Sachs, 1999). Schön (1984) 'un da belirttiği gibi, tasarım eğitimi tasarım eğitim programlarında en önemlisidir ve tasarım stüdyoları bu sınıfların uygulama yeri olarak görev yapmaktadır. Eğitim, özellikle tasarım eğitimi almayan öğrencilerin tasarımlarını ilk kez görüp deneyimledikleri tasarım stüdyolarında tasarlanmalıdır. Ayrıca tasarım stüdyosunda yeni bir tasarım dili öğretilmeli ve tasarım eğitimi ile bütünleştirilmelidir. Bu nedenle, tasarım stüdyosunun amacı, öğrencileri hayal gücünü ve kendini ifade etmelerini sağlamak ve 
gelecek için yeni deneyimler kazanmalarını sağlamak için öğrencilere her türlü şartlamadan feragat ettirmek olmalıdır (Melikeoğlu Eke ve Usta, 2016).

Boyer ve Mitgang (1996); çokluklarının, olasılıklarının ve kısıtlamalarının bütünleştiği bir düşünme şekli olan mimarlık bilgisini bir süreç olarak tanımlamaktadır. Tasarım stüdyolarının bir araya getirdiği bir dizi eğitimin, mimari eğitimin birçok unsurunu aşamalı olarak bir araya getiren bağ dokusunu sağladığını savunmaktadır. Tasarım disiplininin odağını oluşturan tasarım sürecinin, kendisini sürekli yenileyen ve deneyimler üreterek ve sorgulama üzerine yeni deneyimler kazanarak ürünler üreten bir yapıya sahip olduğu düşünülebilir. Dolayısıyla süreç aslında analiz, sentez ve değerlendirme adımlarının birbirini takip ettiği tek yönlü bir süreç değil, geri dönüşlerle yenilikler ve farklılıklar yaratan zengin bir deneyim kaynağıdır (Melikeoğlu Eke ve Usta, 2016). Çözülmesi gereken bir tasarım sorununu formüle etmek için sınırları belirlenmeli, dikkat edilmesi gereken belirli konular ile ilişkiler seçmeli ve duruma sonraki hareketleri yönlendiren tutarlılık getirilmelidir. Dahası, çerçeveleme çalışmaları, bir tasarım sürecinin başlangıcında nadiren gerçekleşir. Tasarım için problem çözmek ve sorun belirlemek yeni ölçütlere ilişkin farkındalığı yaratır (Schön, 1988).

Tasarım stüdyosu, öğrencilerin kabiliyetlerinin gelişmesini ve mimarlık hakkında kendi fikirlerini açıklayabildikleri bir çevredir. Birebir kritiğin pedagojik elemanları, jüri sistemi ve geri beslenme bunun sonuçları olarak algılanabilir ve bunlar açıklayıcı eğitimin aşamaları olarak yer alır (Ketizmen, 2003). Tasarım süreci ilk aşamadan başlayarak tasarım için hazırlık çalışmalarından, tasarım düşüncesinin ortaya çıkması ve tartışııması aşamasına kadar uzanır. Tasarım öğretisinde analiz, sentez ve değerlendirmenin yaratıcı süreçle doğrudan ilişkilidir (Ketizmen, 2002). Uluoğlu (2000); tasarım aşamalarını altı başlık altında toplamıştır:

- Giriş: Stüdyo hedeflerini, gereksinimlerini ve proje konusunu tanıtmak

- Yer/Alan Analizi: Çevre ile ilgili verileri ve alanı araştırmak

- Yerleşim (Leke Etüdü): Gözlemlerin sonucunda elde edilen veriler ışığında tasarıma başlamak

- Projenin Ana Fikri: Bir bina programı ya da kavramları göz önünde bulundurarak tasarım yapmak, projenin konseptini belirlemek

- Destekleyici bilgi: Mevcut binaları ve tasarım teorilerini incelemek

- Bina (sistemler): Bina sistemleri ve detayları hakkında bilgi sahibi olmak

Günümüzde teknolojinin gelişmesi ve bilimin hızla ilerlemesinden dolayı mimari tasarım eğitiminde çeşitli yöntemler kullanılmaktadır. Geleneksel yöntemlere bilgisayar destekli eğitim modelleri eklenmekte ve tasarımda iki boyutlu düşünmenin yanı sıra üç boyutlu düşünme yeteneğinin oluşturulması sağlanmaktadır. Teknolojinin gelişmesi ve mimari tasarım programlarının sayısının ve özelliklerinin artması ile tasarım süreci de hızlanmıştır. Fakat tasarım yöntemleri ve uygulanan metotlar farklı olsa da öğretme yöntemleri temel olarak değişiklik göstermemektedir. Bu kapsamda Demirel (1999) tarafından açıklanan genel öğretme yöntemlerini mimarlık eğitimine uyarlayan (Ketizmen, 2003) şu şekilde sıralamıştır:

- Anlatım Yöntemi: Ders yürütücülerinin tasarım problemi hakkında teorik bilginin aktarılmasıdır.

- Tartışma Yöntemi: Bir konunun kavranması aşamasında karşılıklı görüşler belirtilirken bir problemin çözüm yollarını ararken ve değerlendirme çalışmaları yaparken kullanılır. Mimarlık eğitimi süresinde jüri, grup ve bireysel kritikler; değerlendirme yöntemi olarak kullanılan açık jüriler bu yöntem altındadır.

- Örnek Olay Yöntemi: Öğrencinin uygulama yapmasını sağlayan ve sınıf ortamında gerçek hayatta karşılaşılan bir problemin çözülmesidir. Konu hakkında daha önce yapılmış olan çalışmaların incelenmesi ve tasarım esnasında karşılaşılan problemlerin çözümlenmesine olanak vermektedir.

- Uygulamaya Yönelik Tasarım Yöntemi: Anlatılan teorik bilginin somutlaştırılması ve tasarım problemine ilişkin uygulamaların yaptırarak öğretme yöntemidir. Öğrencinin üç boyutlu maket ve modelleme çalışmaları ile bilginin beceriye dönüştürülmesi sağlanmaktadır.

- Problem Çözme Yöntemi: Problem çözümünde genelleme ve sentez yapmada ve araştırma yoluyla öğrenme yaklaşımında kullanılmaktadır. Öğrencinin tasarım sürecinde karşılaşılan problemleri çözerek öğrenmesi hedeflenmektedir. 
- Bireysel Çalışma Yöntemi: bir öğrencinin bir konuyu ya da uygulamayı yaparak öğrenme yöntemidir. Uygulama, analiz ve sentez düzeylerindeki davranışları kazandırmada kullanılmaktadır. Mimari tasarım eğitiminde öğrencinin verilen tasarım problemine yönelik uygulamalarının tek başına yaparak öğrenmesi sağlanmaktadır.

Tasarım aşamasının her esnasında tasarım stüdyolarında çeşitli eleştiri ortamları oluşturulur. Tok ve Ayyıldız Potur (2016); eleştirinin amacını "tasarımı, tüm süreç ve nesnel verileri ile çok boyutlu bir zemin üzerinde, çok girdili ağlarıyla tartışmaya açmak" olduğunu ve bu nedenle stüdyo ortamında birden fazla tip eleştiri metodu uygulandığı vurgulamaktadır. Tasarım farklı aşamalarında farklı eleştiri tiplerine gerek duyulmaktadır. Proje sürecinde öğrenci grubu, sayısı, sınıf düzeyi, yürütücü sayısı ve proje tasarım konusu gibi etkenlerden dolayı farklı eleştiri metotları uygulanmaktadır. Oh vd. (2013); stüdyo dersi eleştiri ortamlarını masa eleştirisi, grup eleştirisi, ara değerlendirme, final değerlendirme ve enformel etkileşim olmak üzere beş başlık altında toplamıştır.

Mimari tasarım eğitimin bu güçlükleri nedeniyle, tasarımın analizle başlayıp sentezle biten doğrusal bir süreç olmayıp, sürekli geri beslemeyle ilerleyen dairesel aşamalı bir problem çözüm süreci olduğu kabul edilmiş bir tanımdır (Rittel, 1985). Bu çalışmada sürecin oldukça önemli olduğu mimari tasarım eğitiminde kısıtı zaman diliminde gerçekleştirilmiş yaz okulu deneyimi değerlendirilmiştir. Başta zaman olmak üzere, öğrenci eğitim düzeyi, öğrenci-kent ve öğrenci-yürütücü adaptasyon problemi gibi sınırlılıkları olan yaz okulu mimari tasarım eğitiminde stüdyo 5 ve 6 öğrencilerinin katılımı ile gerçekleşen deneyim süreci olarak öğrencinin devamlılık ve performansları incelenirken, sonuç ürün olarak ise öğrencilerin proje çıktıları ve geçme notları incelenmiştir.

\section{MATERYAL VE YÖNTEM}

\subsection{Materyal}

Mimarlık eğitiminde kısıtlı zaman içerisinde yürütülen yaz okulu döneminin sürecini, sınırlııklarını ve normal dönemden farkını belirlemeyi amaçlayan bu çalışmanın materyalini öğrencilerin stüdyo eğitimi sürecinde derse devamlılık durumları, stüdyo yürütücülerinden kritik alma oranları, süreç içerisinde gösterdikleri performans ve final teslimleri oluşturmaktadır. Bu çalışmada Selçuk Üniversitesi yaz okulu kapsamında Bina Bilgisi ve Restorasyon Anabilim Dalı'ndaki iki ders yürütücüsü ile iki farklı atölyede ortak proje alanı ve intiyaç programı kapsamında eş zamanlı yürütülen mimarlık stüdyo 5 ve 6 dersi öğrencilerinin katılımı ile atölye çalışması yapılmıştır. Mimarlık tasarım eğitiminin normal dönemde 14 hafta/112 saat olmasına rağmen, yaz okulunda sürecin 7 hafta olması nedeni ile proje 5 öğrencileri için salı ve perşembe günleri, proje 6 öğrencileri için ise çarşamba ve cuma günleri olmak üzere haftada iki gün 8 saatlik dersler yapılarak toplam 112 saat ders yapılmıştır. Böylece normal dönem ile yaz okulu dönemi ders saatleri süre olarak birbiri ile eşitlenmiştir. Çalışma kapsamında yaz okulu kapsamında stüdyo eğitiminde 7 farklı üniversiteden (Bolu Abant İzzet Baysal Üniversitesi, Çukurova Üniversitesi, Dicle Üniversitesi, Düzce Üniversitesi, Erciyes Üniversitesi, Karabük Üniversitesi, Van Yüzüncü Yıl Üniversitesi) farklı sosyal, ekonomik ve kültürel özelliklere sahip 21 öğrencinin proje süreçleri ve final teslimleri üzerinden değerlendirme yapılmıştır.

\subsection{Yöntem}

Çalışma kapsamında farklı üniversitelerde öğrenim gören ve yaz okulu kapsamında Selçuk Üniversitesi Mimarlık Fakültesi Mimarlık Bölümü'nde eğitim görmeye gelmiş olan 21 öğrencinin proje süreci ele alınmıştır. Çeşitli üniversitelerde öğrenimine devam mimarlık öğrencilerin yeni bir üniversitenin eğitim sistemine adaptasyon durumları göz önünde bulundurularak proje süreci farklı şekilde programlanmıştır. Bu kapsamda öğrencilerin daha önce çalıştıkları proje konularından farklı olmasına önem verilerek, proje alanı ve konusu yürütücüler tarafından belirlenmiştir. Yaz okulu süreci programlanırken sınırlılıklar göz önünde bulundurularak, ilk iki hafta öğrencinin Selçuk Üniversitesi Mimarlık Bölümü eğitim modeline adaptasyon sürecinin sağlanması ve ders yürütücüsü ile uyumun oluşturulması amacıyla yürütücüler tarafından teorik bilgi aktarımı yöntemi kullanılarak sunumlar yapılmıştır. Öğrenci ile interaktif sınıf ortamı oluşturulması ve öğrencinin proje esnasında karşılaşacağı sorunları kolaylıkla çözebilmesi amacıyla, örnek olay yöntemi kullanılarak 
öğrencilere proje konusu hakkında araştırmalar yaparak stüdyo ortamında sunmaları istenmiş ve örnekler üzerinden tartışmalar yapılmıştır. Öğrencilerin proje alanını tanımamalarından dolayı yürütücülerle birlikte teknik gezi yapılmış ve gezi esnasında mevcut alanın yapılı çevre, doğal çevre, yaya ve araç ulaşım analizleri öğrencilerle birlikte arazi gezisi esnasında yapılmıştır. İlk iki haftadan sonra ise öğrencilerin proje eleştirileri Oh vd. (2013)'nın belirlediği yöntemlerden olan masa eleştirisi yöntemi kullanılarak verilmiştir. Proje kritiklerinin beş hafta devam ettiği süreçte iki ara jüri yapılarak tartışma yöntemi ile bilgi alışverişi gerçekleştirilmiş ve son olarak bir final değerlendirmesi yapılmıştır. Yedi haftalık süreç boyunca istatistiki verilerin elde edilmesini sağlamak amacıyla devamsızlık durumları ve kritik alma yüzdeleri akış şemasına kaydedilmiştir. Belirlenen hedeflere belirlenen sürede ulaşıp ulaşılmadığını tespit etmek için ise proje ilerleyişi, sınıf içi uygulamalar ve proje çıktıları incelenmiştir. Sonuç olarak elde edinilen veriler ise öğrencilerin derse devam oranları ve kritik alma oranları ile proje çıktıları ve proje geçme notları arasında doğrusal bir ilişki olup olmadığı ölçülmeye çalışılmıştır.

\section{BULGULAR}

\subsection{Sürecin Programlanması}

Yaz okulu dönem içinde derslerinde başarılı olamayan veya dersi dönem öncesinde almak isteyen öğrenciler için yaz döneminde öğrenimine devam ettiği ya da farklı bir üniversitede ders alabilmesine olanak tanıyan eğitim programıdır. Bu doğrultuda yaz okulu stüdyo eğitimi kapsamında Bina Bilgisi ve Restorasyon Anabilim Dalı'ndaki iki yürütücü ile iki farklı atölyede 7 farklı üniversiteden katılan stüdyo 5 ve 6 öğrencileri ile atölye çalışması yapılmıştır. Atölyede farklı proje düzeyine sahip gruplar bir arada birleştirilerek dikey stüdyo uygulaması yapılmasının yerine; iki grup stüdyo eğitimi farklı atölyelerde yapılarak yatay stüdyo eğitimi izlenmiştir. Sürecin etkin kullanılması ve ders akışının kontrol altında tutulması amacıyla iki atölye için 7 hafta boyunca verilen 14 derse yönelik ortak takvim oluşturulmuş ve süreç programlanmıştır (Tablo 1).

Tablo 1. Yaz Okulu Programı

\begin{tabular}{|c|c|c|c|}
\hline 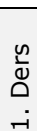 & $\begin{array}{l}\text { Proje Konusunun, } \\
\text { Alanının } \\
\text { Belirlenmesi }\end{array}$ & $\Rightarrow$ & \\
\hline$\frac{n}{\mathscr{N}}$ & $\begin{array}{l}\text { Teorik Anlatımlar } \\
\text { Öğrenci Sunumları } \\
\text { İhtiyaç Programı }\end{array}$ & $\Rightarrow$ & $\frac{1}{\pi}$ \\
\hline 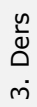 & $\begin{array}{l}\text { Teorik Anlatımlar } \\
\text { Öğrenci Sunumları } \\
\text { Fonksiyon Şeması }\end{array}$ & & 焦 \\
\hline $\begin{array}{l}\frac{n}{0} \\
\stackrel{+}{\square}\end{array}$ & Teknik Gezi & & $\overline{\bar{n}}$ \\
\hline $\begin{array}{l}\frac{n}{d} \\
\frac{2}{0} \\
\text { in }\end{array}$ & Analizler & $\Rightarrow$ & \\
\hline
\end{tabular}

\begin{tabular}{|c|c|}
\hline $\begin{array}{l}\frac{n}{0} \\
\stackrel{0}{0} \\
\dot{\omega}\end{array}$ & $\begin{array}{c}\text { Analizler } \\
\text { Ana Fikir } \\
\text { Leke Çalışmaları }\end{array}$ \\
\hline 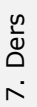 & $\begin{array}{l}\text { Arazi Maketi } \\
\text { Kütle Maketleri } \\
\text { Vaziyet Planı }\end{array}$ \\
\hline $\begin{array}{l}\frac{n}{2} \\
\stackrel{0}{0} \\
\infty\end{array}$ & $\begin{array}{c}\text { Vaziyet Planı } \\
\text { Kat Planları Kütle } \\
\text { Çalışmaları }\end{array}$ \\
\hline $\begin{array}{l}\frac{n}{4} \\
0\end{array}$ & $\begin{array}{l}\text { 1.Değerlendirme } \\
\text { (Açık Jüri) }\end{array}$ \\
\hline $\begin{array}{l}\stackrel{n}{2} \\
\stackrel{0}{0} \\
\dot{0} \\
-1\end{array}$ & $\begin{array}{c}\text { Kat Planları } \\
\text { Arazi Kesitleri } \\
\text { Siluet ve Maket } \\
\text { Çalışmaları }\end{array}$ \\
\hline
\end{tabular}

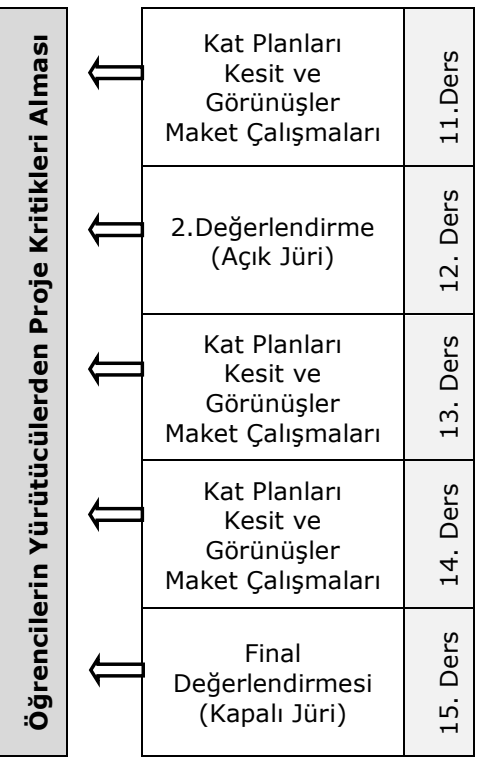

Proje sürecinde öğrencilerin önceki çalıştığı konulardan farklı olmasına önem verilerek, proje alanı olarak Konya/Merkez'e $8 \mathrm{~km}$ uzaklıkta geleneksel bir dokuya sahip olan Sille'de bir tasarım alanı seçilmiş ve proje konusu ise butik otel tasarımı olarak belirlenmiştir. Tarihi öneme sahip eski bir yerleşim yeri olan Sille'nin seçilme nedeni, Konya'nın kendine özgü geleneksel dokusu korunmuş olan bölgesinin öğrenciler tarafından çalışılmasının istenmesidir. Konyalı (1964) Sille'nin; M.Ö. Hititler ve Frigyalılar, M.S. ise Romalılar, Bizanslar, Selçuklular, Karaman oğulları ve Osmanlılar dönemlerinde yerleşim merkezi olmasından dolayı farklı kültür, inanç, gelenek ve coğrafi yapısıyla dikkat çeken en az 5700 yıllık tarihi bir geçmişe sahip olduğunu vurgulamaktadır. Eğimli bir araziye sahip olan proje alanı çevresinde Aya 
Eleni Kilisesi, Süt Kilisesi, Kaya Oyma Kiliseleri, Kurtuluş Camii, Mormi Camii bulunmaktadır (Şekil 1).

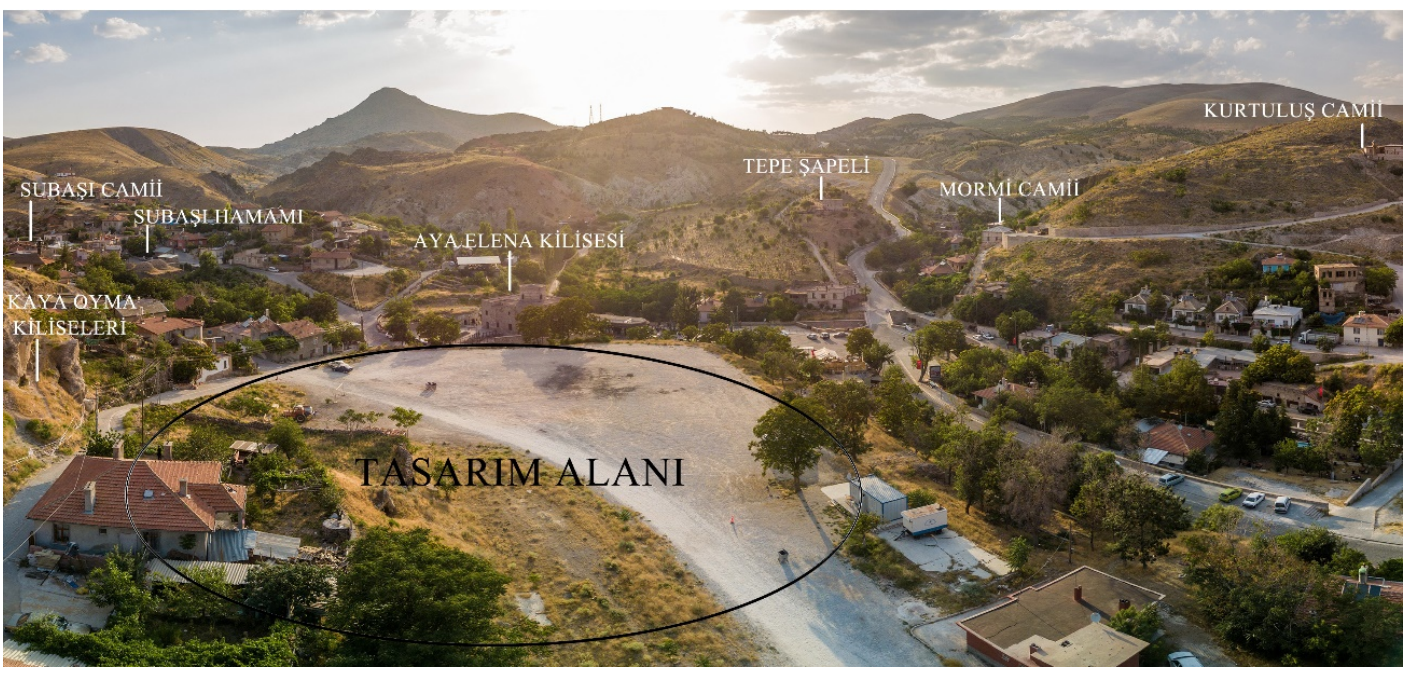

Şekil 1. Yaz Okulu Proje Alanı

İki farklı atölyede ortak olarak yürütülen yaz okulu programında öğrencilerin eğitim düzeylerindeki farklılıklar, öğrenci ile yürütücü arasında yaşanan adaptasyon problemlerinin çözümlenmesine yönelik proje süreci uyarlanmaya çalışılmıştır. Bu kapsamda ilk 4 ders kapsamında teorik anlatımlar ve sınıf içi uygulamalar yapılırken, sonraki derslerde öğrencinin proje yürütücüsünden aldığı kritikler doğrultusunda devam edilmiştir. Proje sürecinde çalışma konusunun ve alanının belirlenmesinden sonra proje konusunun daha iyi anlama ve kavrama amacıyla, yürütücüler ve öğrenciler tarafından konu ile ilgili yurtiçi ve yurtdışı örnekleri, çalışma konusu olan butik otel tasarımları ve mekan kurguları, çalışma alanı olan Sille'nin incelenmesi, tarihi çevre kavramı, yerel kimlik kavramı, yere özgü tasarım, eğimli arazide tasarım örnekleri incelenmiş ve diğer teorik konularda anlatımlar gerçekleştirilmiştir.

Tablo 2. Öğrenci Analiz Çalışmalarından Örnekler

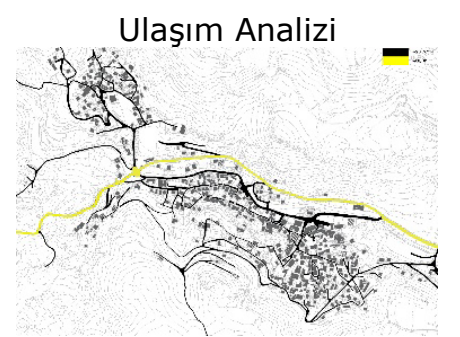

Tescilli Yapıların Analizi

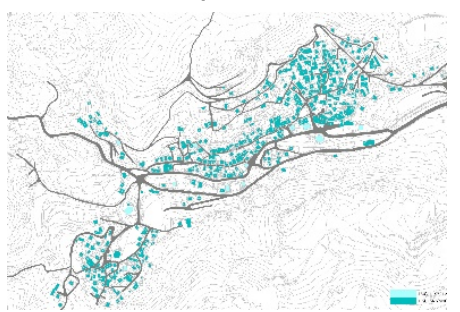

Doluluk-Boşluk Analizi

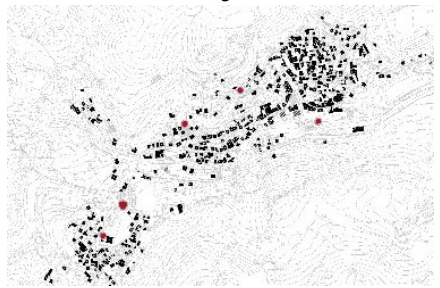

Yeşil Alan Analizi

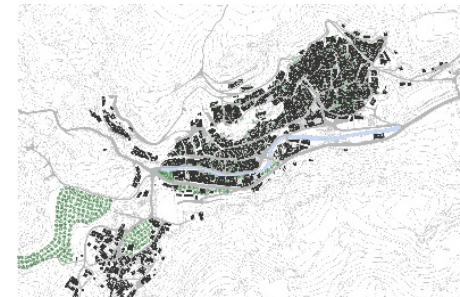

Odak Noktaları

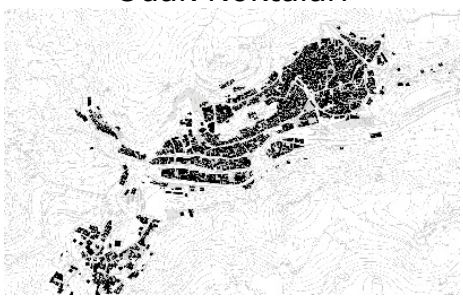

Kat Yüksekliği Analizi

Öğrencilerin alanı tanımamaları ve süre kısıtlılı̆ı nedeni ile çalışma alanı olarak belirlenen Sille'ye bir günlük teknik gezi gerçekleştirilmiştir. Gezi esnasında mevcutta bulunan Hıristiyanlık Dönemine ait Aya Eleni Kilisesi, Tepe Şapeli, Sille Mağara Kiliseleri, İslamiyet Dönemine ait Sille'nin tarihi camileri, geleneksel sokak dokusu ve atölyeleri gezdirilerek Sille'nin tarihi geçmişi ve tarihi önemi anlatılmıştır. Çalışma alanında projenin sürecini etkileyecek olan mevcutta bulunan tarihi yapılar, geleneksel doku, yaya ve araç ulaşımı, yeşil doku gibi doğal ve yapay çevre analizlerinin yerinde yapılması sağlanmaya çalışılmıştır (Tablo 2). Proje kapsamında eğimli bir arazi yerleşimi olan Sille'nin genellikle iki katlı tarihi dokusu ve silueti göz önünde bulundurularak, 30 odaya sahip butik otel tasarımı yapılması 
istenmiştir. Tasarımın ihtiyaç programı; giriş, yönetim, yemek, konaklama, dinlenme-etkinlik, hizmet, teknik, rekreasyon alanları ve otopark bölümlerinden oluşmaktadır (Tablo 3). Öğrencilerin butik otel tasarım yaparken dikkat edilmesi gerekenler bazı unsurlar projenin başından bitişine kadar her safhada belirtilmiştir. Bu unsurlar;

- Sille'nin geleneksel tarihi dokusu göz önüne alınarak tasarım yapılması,

- Proje alanının eğimli olması nedeni ile eğime uygun proje tasarlanması,

- Ş̧ehir merkezinden başlayarak ulaşımın düşünülmesi ve projenin her birey için erişilebilir olması,

- Parçalı kütleler çözümlenmesi halinde, yapıların birbiri ile bağlantılarının yarı açık ve açık mekanlar ile kurulması,

- Konaklama bölümünde farklı kullanıcılara uygun tek, iki ve dört kişilik odaların tasarlanması,

- Düşey olarak çözümlenen katlardan her birinde yönetmeliğe uygun, içinde bir adet servis merdiveni ve bir adet servis asansörünün bulunduğu bir kat ofisi çözümlenmesi,

- Restoran ile mutfağın, mutfak ve depoların hem birbiriyle hem de servis girişi ile bağlantısının düşey ya da yatay sirkülasyon ile sağlanması,

- Çamaşırhane ile kat ofisinin bağlantısının sağlanması,

- Fitness salonu, Türk hamamı, sauna ve buhar odası gibi dinlenme mekanlarında soyunma bölümünde temiz ve kirli ayak bölümünün ayrılması,

- Sille'deki el sanatları atölyelerinin sürdürülebilirliğini sağlamak amacıyla atölyede yapılan eserleri sergilemek için sergi salonunun gerekli olması ve buna ek olarak halka açık birimler olması şeklinde sıralanabilir (Tablo 4).

Tablo 3. Yaz Okulu İhtiyaç Programı

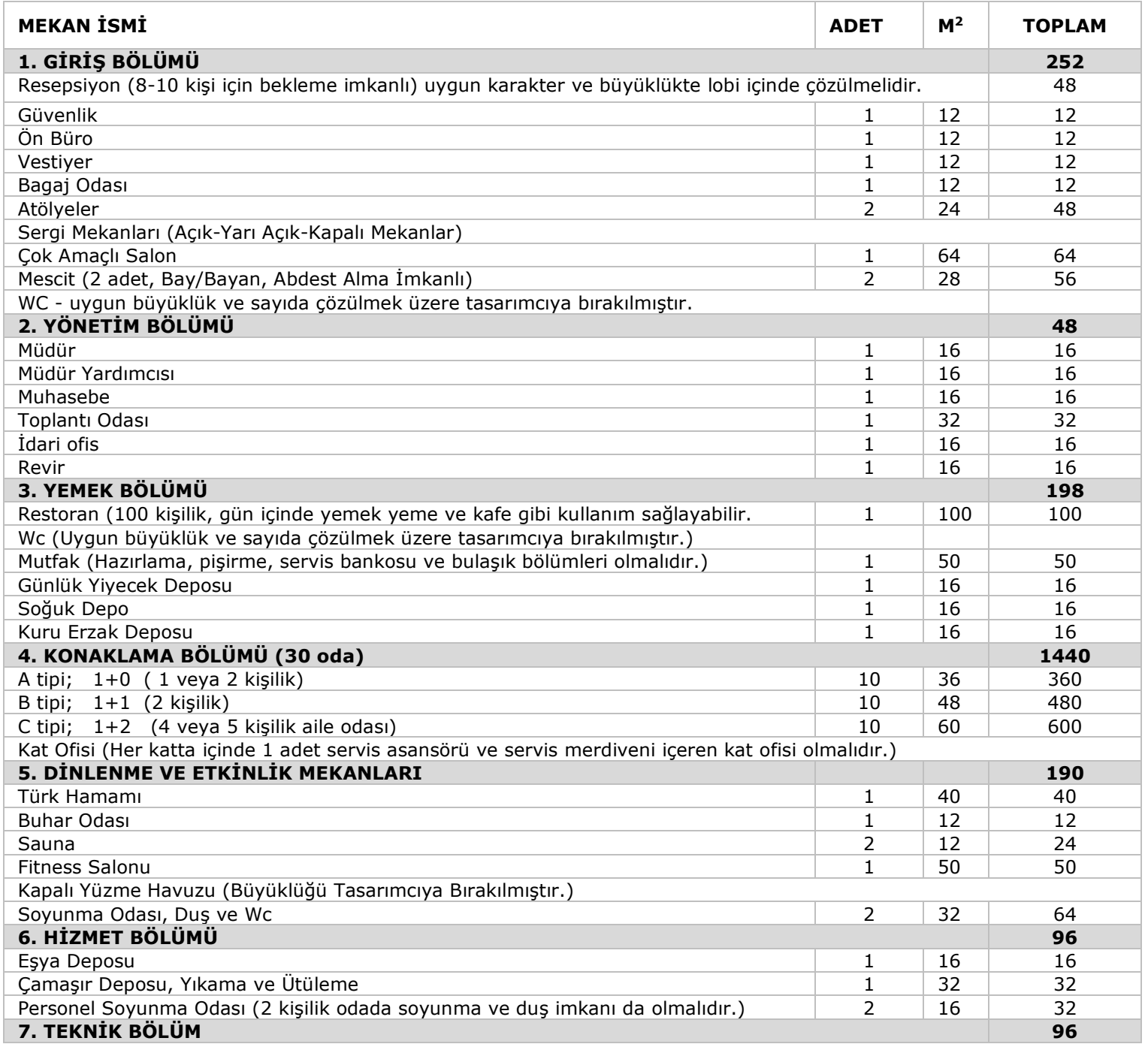




\begin{tabular}{|c|c|c|c|}
\hline Isıtma & 1 & 24 & 24 \\
\hline Havalandırma - Klima (Genel Mekanların Tamamında Olacaktır.) & 1 & 24 & 24 \\
\hline Elektrik Odası & 1 & 24 & 24 \\
\hline Su Deposu & 1 & 24 & 24 \\
\hline Jeneratör Odası & 1 & 24 & 24 \\
\hline Genel Depo & 1 & 24 & 24 \\
\hline \multicolumn{4}{|l|}{ 8. REKREASYON ALANLARI } \\
\hline \multicolumn{4}{|c|}{ Uygun sporlar, yürüyüş yolları, oturma ve dinlenme alanları, hobi bahçeleri olan rekreasyon alanları tasarlanabilir. } \\
\hline \multicolumn{4}{|c|}{ 9. OTOPARKLAR } \\
\hline \multicolumn{4}{|c|}{$\begin{array}{l}\text { Minimum } 25 \text { araç kapasiteli otopark olacaktır. } \\
\text { TOPLAM ALAN }\left(2400 \mathbf{~ m}^{2}\right)+\text { SİRKÜLASYON } \% 10\left(240 \mathrm{~m}^{2}\right): \text { GENEL TOPLAM }\left(2640 \mathrm{~m}^{2}\right)\end{array}$} \\
\hline
\end{tabular}

Atölye çalışması sırasında katılan öğrencilerin farklı üniversitelerden olması ve aldıkları eğitim modellerinin birbirinden farklı olmasından dolayı, öğrencilerin birbirlerine adaptasyonunun sağlanması gerekmiştir. Bu nedenle uyumlu bir atölye ortamını oluşturmak amacıyla öğrenciler gruplara ayrılarak, grup çalışması halinde proje alanına yönelik doğal çevre ve yapay çevreye yönelik analiz paftaları hazırlamaları istenmiştir. Projenin tasarımına geçilen aşama olan leke etüdü çalışmaları, konsept paftaları ve kütle maketleri ise bireysel çalışmalar ile üretilmiş ve öğrencilerin bireysel problem çözme yöntemi ile tasarımlarını gerçekleştirmeleri beklenmiştir. Devam eden proje sürecinde tartışma yönteminin sağlanması amacıyla masa kritikleri verilirken; atölye süreci sonunda üretilen tasarımlar açık jüri şeklinde iki vize ve kapalı jüri şeklinde bir final sınavı yapılarak değerlendirilmiştir.

Tablo 4. Butik Otel Projesi Fonksiyon Şeması

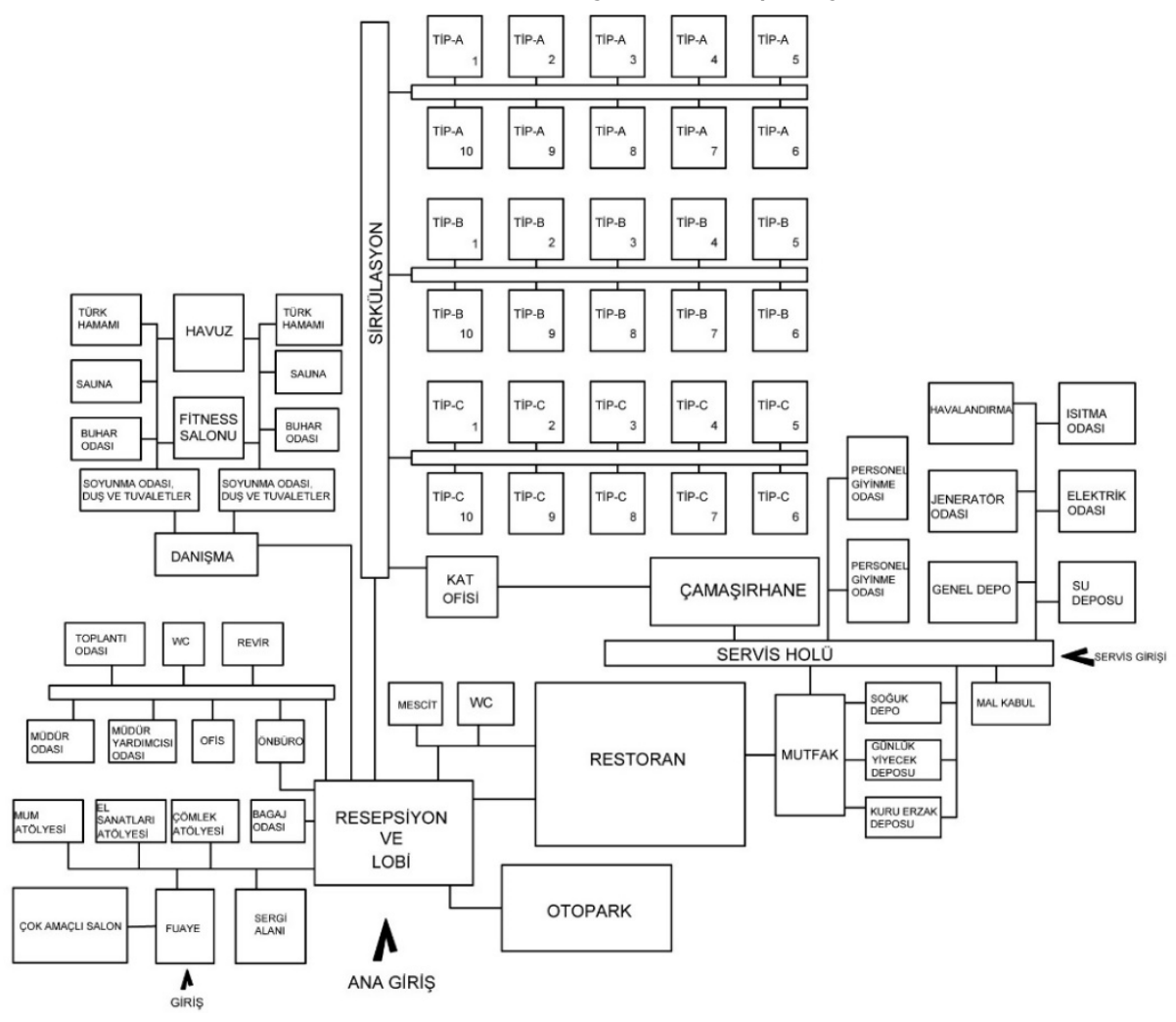

\subsection{Devamlılık-Atölye Performans İlişkisinin İncelenmesi}

Stüdyo eğitimde önemli olan atölye performansı ve zaman yönetimi kısıtlı bir süreç olan yaz okulunda daha da önem arz etmektedir. Öğrencilerin derse devamlılıkları ile atölye içerisindeki performansları ve stüdyo yürütücüsünden kritik alma oranları, sonuç ürünü doğrudan etkilemektedir. Mimarlık eğitiminde atölye performanslarında beklenen; yalnızca devamlılık oranının yüksek olması değil, süreç içerisinde sınıf içerisinde etkin katılım, yürütücülerden kritik alma oranının yüksek olması ve verilen kritikler doğrultusunda tasarım projesinin geliştirilmesidir. Stüdyo eğitiminde esas olan öğrencinin bireysel ya da grup olarak tasarladığı projesinin yürütücüden aldığı eleştiriler doğrultusunda ve atölyede bulunan diğer öğrencilerle fikir alışverişinde bulunarak sürenin doğru kullanımı ile süreç içerisinde tasarımın 
yapılmasıdır. Bu noktada yaz okulu kapsamında stüdyo 5 ve 6 düzeyinde 21 öğrencinin derse devamlılık ve atölye performans oranları haftalık akış şeması içerisinde notlar alınarak, elde edilen veriler istatistiki verilere dönüştürülmüştür. Devamlılık oranları ve öğrenci performansları belirlenirken 15 ders süresi (\%100) üzerinden oranlanmıştır. Öğrencinin devamlılık oranı derse devam etme yüzdesi olarak belirlenmiştir. Bunun yanı sıra öğrencinin dersi etkin kullanıp kullanmadığını araştırmak amacıyla, öğrencinin atölye performansı da 15 ders süresi (\%100) üzerinden oranlanmıştır. Böylece öğrencinin atölye içi katılım ve proje yürütücüsünden kritik aldığı ders oranı istatistiki olarak hesaplanmıştır.

Tablo 5. Öğrencilerin Devamlılık-Atölye Performans İlişkisi

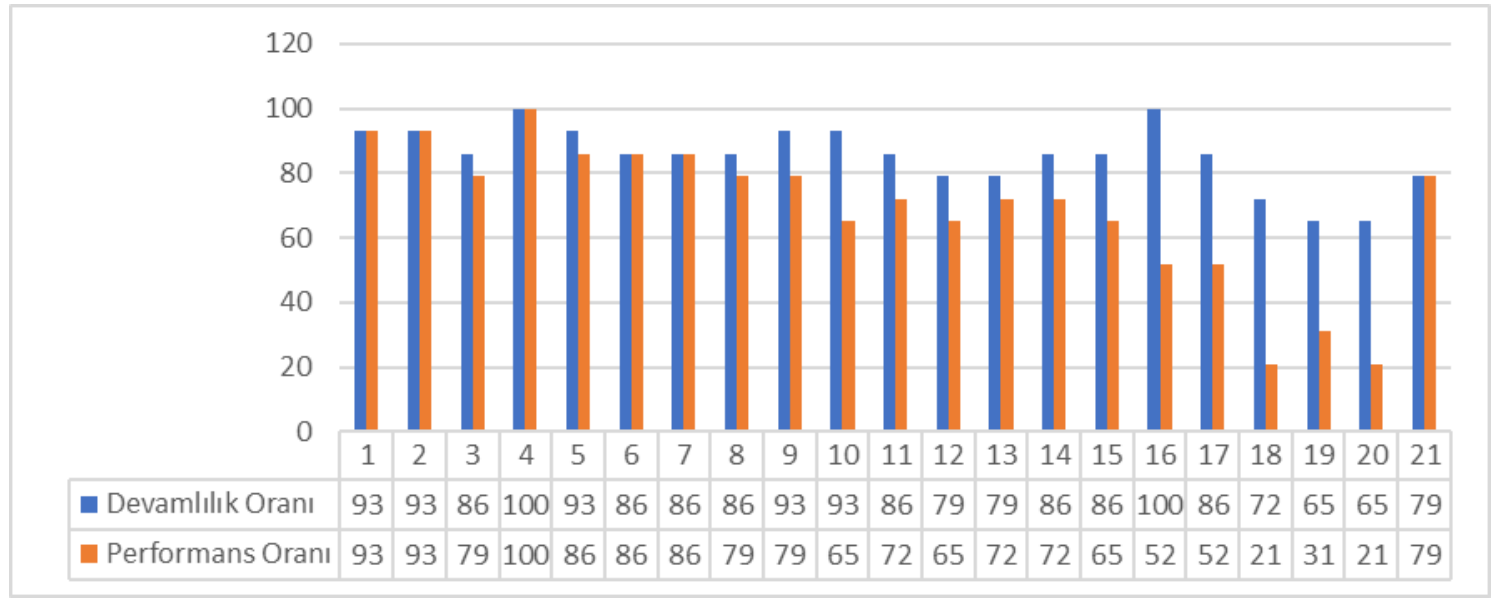

Elde edinilen veriler incelendiğinde; öğrencilerin devamlılık oranının \%100 ile \%65 arasında değişkenlik göstermesine rağmen, atölye performansını \%100 ile \%21 arasında değişkenlik gösterdiği gözlenmiştir. Yaz okulu öğrencilerinin devam ve performans yüzdeleri karşılaştırıldığında; öğrencilerin derse devam etmelerine rağmen süreci etkin kullanamadıkları ve stüdyo yürütücülerinden projelerini hakkında herhangi bir kritik almadıkları tespit edilmiştir. Öğrencilerin devam-performans grafiği incelendiğinde 15 ders saatinin 14'üne katılan ve 14 ders boyunca yürütücülerden kritik alan Öğrenci-1 \%93 ile yüksek performanslı öğrenci olurken, 15 ders saatinin 11'ine katılan ve sadece 3 ders kritik alan Öğrenci-15 \%21 ile düşük performanslı öğrenci olarak karşımıza çıkmaktadır (Tablo 5).

\section{3. Çıktılar}

Yaz okulu kapsamında yedi haftalık süre sonunda öğrencilerden Sille yerleşiminde verilen probleme yönelik butik otel proje tasarımı yapılması ve tasarımın vaziyet planı, kot planları, kesitleri, görünüşleri, maketi, üç boyutlu modelleme çalışmaları istenmiştir. Atölyenin çalışmasının sonunda öğrenciler tasarıma yönelik belirlediği konsepti, proje alanına yönelik analiz ve sentez çalışmaları neticesinde alınan proje çıktıları incelenmiştir. Süreç boyunca devamlılık oranları, performansları ve final değerlendirme jürisinde teslim edilen projeler yürütücüler tarafından yapılan değerlendirmeler ve sonuç ürünler Tablo 6'de listelenmektedir. 
Tablo 6. Öğrencilerin Proje Çıktıları

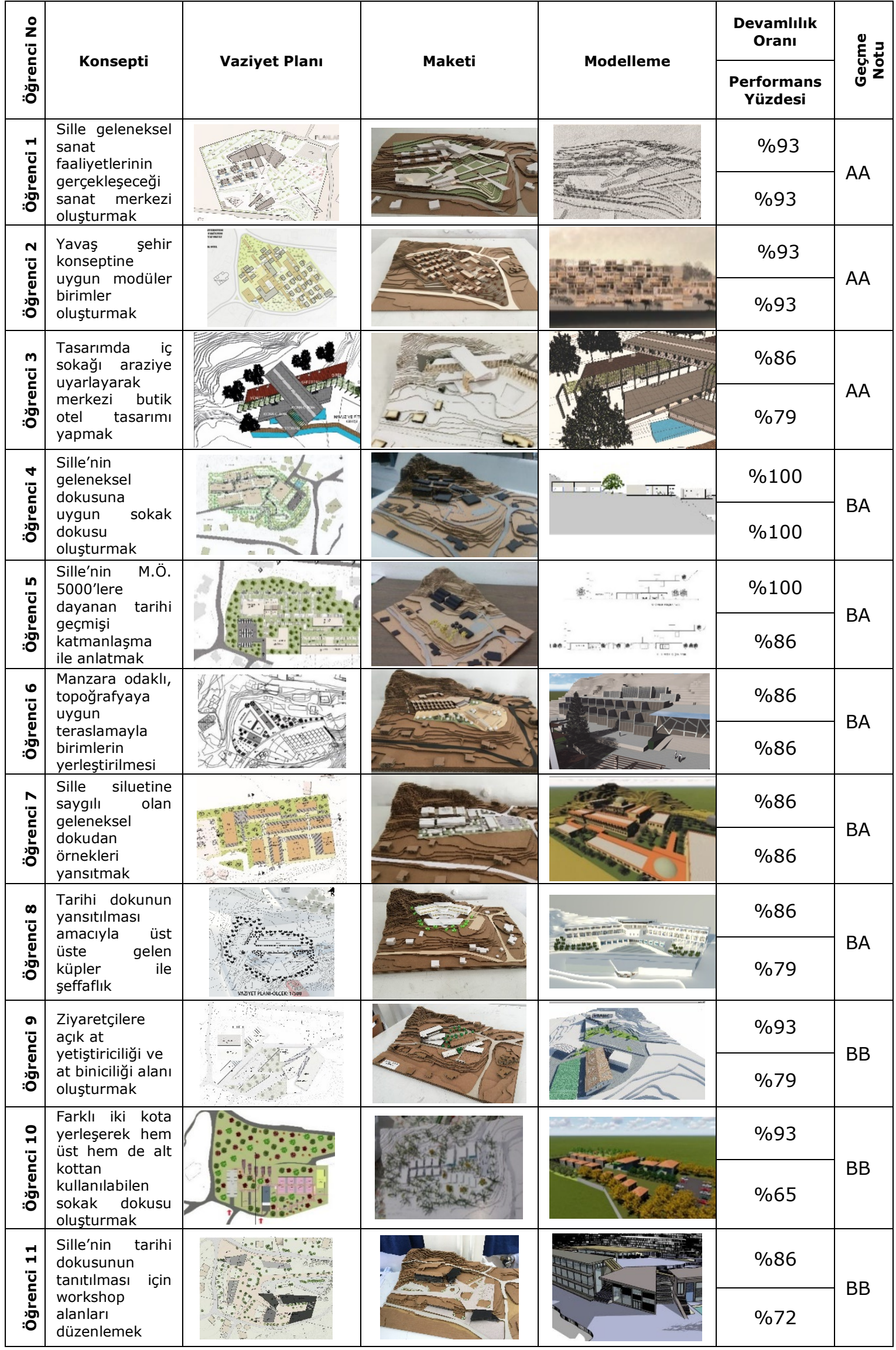




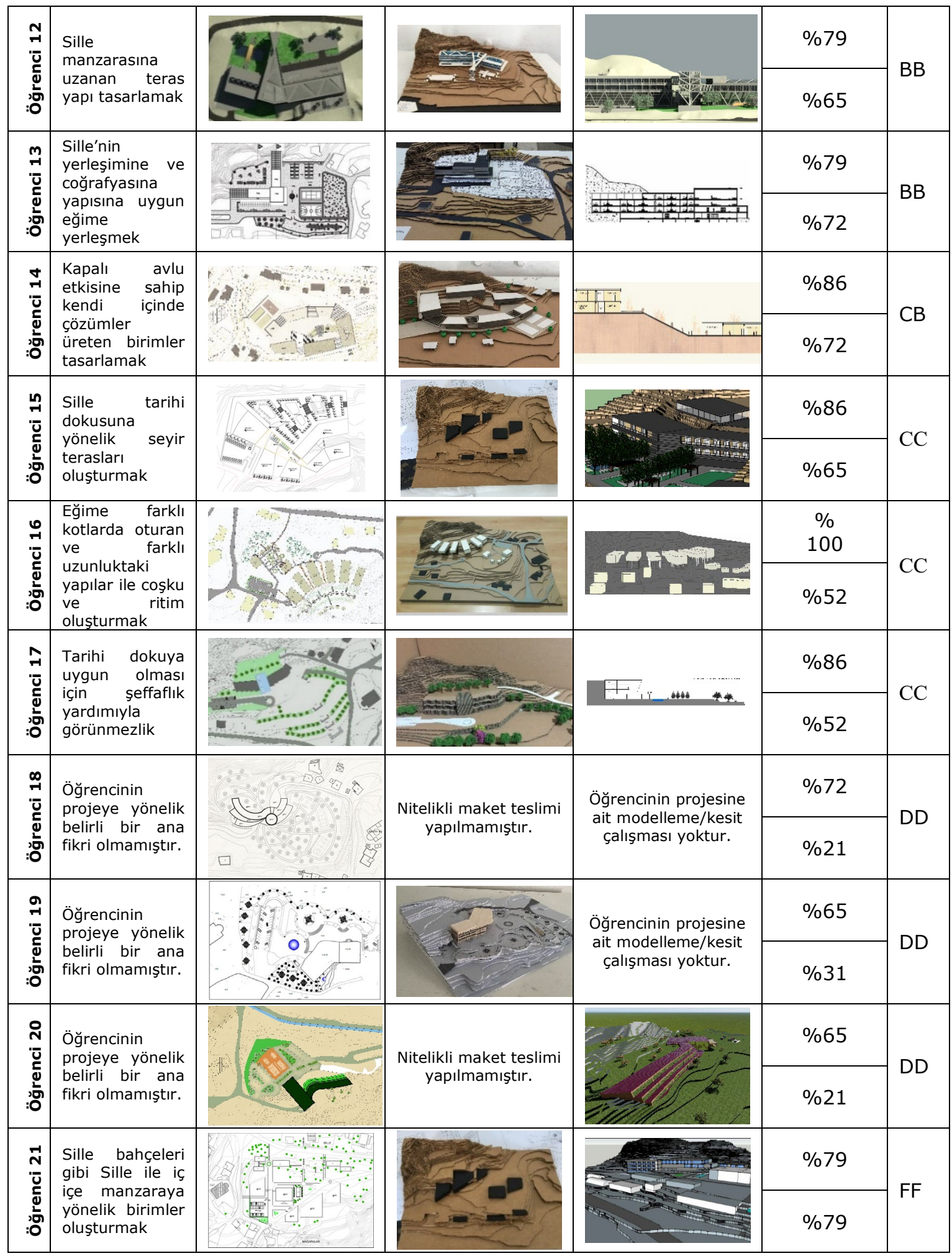

Yaz okulu döneminde 7 haftalık sürecin sonunda sonuç olarak yapılan değerlendirmeler neticesinde geçme notları hesaplanmış ve dersi verimli geçirerek atölye performansı yüksek olan öğrencilerin başarı yüzdesi ile doğru orantılı bir tablo elde edildiği gözlenmiştir. Atölye çalışmasına katılan 21 öğrenciden 17 öğrenci dersi başarı ile tamamlarken, 4 öğrenci DD ve FF geçme notları ile dersten kalmıştır. Bu tablo incelendiğinde öğrenci atölye performansı $\% 79$ ve üzeri olan 9 öğrencinin $A A, B A$ ve $B B$ geçme notu ile tespit edilirken; atölye performansı $\% 72$ ve $\% 65$ olan orta seviyede öğrencilerin $B B, C B$ ve CC gibi orta düzey geçme notları aldığı gözlenmiştir. Elde edinilen veriler sonucunda \%21 ve \%31 gibi düşük 
performansa sahip öğrencilerin DD geçme notuna sahip olduğu tespit edilmiştir. Fakat atölye performansı \%79 olmasına rağmen; 1 öğrencinin teslim yapmamasından dolayı FF ile kaldığı gözlenmiştir (Tablo 7).

Tablo 7. Öğrencilerin Geçme Notu ile Performansları Arasındaki İlişki

\begin{tabular}{|c|c|c|c|c|c|c|c|c|c|c|}
\hline \multicolumn{2}{|c|}{ Öğrenci Performansı } & $\% 100$ & $\% 93$ & $\% 86$ & $\% 79$ & $\% 72$ & $\% 65$ & $\% 52$ & $\% 31$ & $\% 21$ \\
\hline \multirow{8}{*}{$\begin{array}{l}z \\
0 \\
2 \\
0 \\
\text { E. } \\
\mathbb{8} \\
0\end{array}$} & AA $(88-100)$ & & 2 & & 1 & & & & & \\
\hline & BA (80-87) & 1 & & 3 & 1 & & & & & \\
\hline & BB (73-79) & & & & 1 & 2 & 2 & & & \\
\hline & CB (66-72) & & & & & 1 & & & & \\
\hline & CC $(60-65)$ & & & & & & 1 & 2 & & \\
\hline & DC (55-59) & & & & & & & & & \\
\hline & DD (50-54) & & & & & & & & 1 & 2 \\
\hline & $\mathrm{FF}(0-49)$ & & & & 1 & & & & & \\
\hline
\end{tabular}

\section{SONUÇ VE TARTIŞMA}

Mimarlık eğitiminin en önemli yapı taşı olan stüdyo eğitimi diğer meslek gruplarından farklı olarak çeşitli tasarım araçları ve farklı yöntemlerin kullanıldı̆̆ı, teorik anlatımın yanı sıra uygulamalı eğitimin verildiği bir yapıya sahiptir. Her dönem birbirini takip eden teorik ve uygulamalı bir eğitim dizisi olan stüdyo eğitiminin temel amacı, öğrenciye tasarlama sürecini öğretilmesidir. Mimarlık eğitiminde tasarım bilgisinin aktarılarak problemin çözümünün yapılması değil, öğrencinin karşılaştığı problem karşısında kendi tasarım gücünün ortaya çıkarılmasını dolayısıyla problem çözmeyi öğretmek amaçlanmaktadır. Sürekli geri dönüşlerin olduğu ve birbirini tekrar eden bir süreç olan mimarlık eğitiminde asıl hedeflenen yalnızca projenin tamamlanarak sonuç ürüne ulaşılması değil; aynı zamanda öğrencinin süreci deneyimlenmesi, karşılaşılan problemlere getirilen çözümler ve uygulamalı olarak mesleğe hazırlanmasıdır. Bu çalışma da ise, sürecin oldukça önemli olduğu stüdyo eğitimi yaz okulu kapsamında uygulanmış ve elde edinilen deneyim değerlendirilmiştir. Çalışmada farklı değişkenlere sahip yaz okulunda farklı üniversiteden katılan stüdyo 5 ve 6 öğrencilerinin proje süreçleri incelenmiştir.

Atölye çalışmasına katılan 21 öğrenci ile deneyimlenen yaz okulunda, öğrencilerin ve yürütücüleri karşılaştığı sorunlar yürütücü ve öğrenci iş birliğinde çözümlenmeye çalışılmıştır. İlk olarak oldukça zorlu bir eğitim olan stüdyo eğitiminin yaz okulunda 7 hafta/56 saat gibi kısa bir sürede yürütülemeyeceği düşünülerek, haftada iki gün yapılmasına karar verilmiş ve 14 hafta/112 saat ders yapılmıştır. Yaz okulu kapsamında yapılan atölye çalışmasına katılan öğrenciler 7 farklı üniversiteden olup, farklı düzeyde eğitim seviyesine sahiptirler. Öğrencilerin stüdyo tasarımlarına yönelik temel bilgi düzeylerinin eşitlenmesi ve Selçuk Üniversitesi eğitim modeli hakkında bilgi sahibi olması amacıyla öğrencilere proje konusu, stüdyo eğitiminin işleyişi ve stüdyo eğitimi boyunca gerekli olan teorik bilgi aktarımı sunumlar üzerinden yapılmıştır. Ayrıca atölye ortamında öğrenci-öğrenci uyumunun oluşturulması amacıyla öğrenciler gruplandırılarak; proje konusu, proje alanı ve örnek projeler üzerinden yapılan incelemelerin sınıf içinde sunum olarak aktarılması istenmiştir. Öğrenciler ile paylaşılan atölye akış programı genel anlamda uygulanmasına rağmen eğitim seviyelerindeki farklılıklar ve yürütülen programa farklı adaptasyon düzeylerinden dolayı üç ya da dört ders geriden gelen öğrencilerin olmasından dolayı program esnetilmiştir.

Yaz okulunun zaman kısıtlıığından ve ayrıca öğrencilerin Konya kentini kapsamında daha önce proje kapsamında çalışmamış olmasından dolayı proje alanı olarak Konya'ya $8 \mathrm{~km}$ uzaklıkta Sille'de seçilmiştir. Fakat öğrencilerin kent ile adaptasyon problemlerinin çözümlenmesi amacıyla, Sille tarihi merkeze öğrenciler ile 1 günlük teknik gezi düzenlenmiştir. Yaz okulunda verilen eğitim saatinin artırılmasına rağmen, 7 haftalık süre uzatılamadığından sürenin etkin kullanılması ve öğrencinin kenti tanımamasından dolayı analiz süreci proje arazisinde yapılmıştır. Gezi süresince öğrencilerin dikkat etmesi gerekli hususlar aktarılmış, anında yapılan analizler, eskizler ve leke çalışmalar ile proje süreci hız 
kazandırmıştır. Süre kısıtııı̆ından dolayı tasarımda en önemli aşamalardan biri olan analiz ve ana fikir aşamalarından planlamaya hızlı geçiş yapılmıştır.

Günümüzde mimarlık eğitiminde teknolojinin gelişmesi ile kullanılan yöntemlere bilgisayar destekli eğitim modelleri eklenmiş ve bu yöntemler tasarımların kağıda dökülmesi süresini ciddi ölçüde azaltarak, mimari proje sürecini hızlandırmıştır. Yaz okulu sürecinde öğrencilerin gerek tasarımlarının hızlandıııması gerekse hızla gelişen dünyada geri kalmama amacıyla tasarımlarında çeşitli bilgisayar programları kullanmaları istenmiştir. Bu kapsamda tasarım programlarını projelerinde kullanmayan öğrenciler, atölye içinde gruplar oluşturarak çeşitli programlar öğrenmiştir. Final değerlendirmesine yapacakları teslimlerde zorunlu olarak nitelikli sunum paftalarının istenmesi ile öğrencilerin çeşitli iki boyutlu sunum ve görselleştirme programlarının yanında üç boyutlu modelleme programlarının öğrenmeleri de sağlanmıştır.

Yaz okulu kapsamında öğrenci projeleri iki ara ve bir final olmak üzere üç değerlendirme yapılarak, proje çıtıtıarına göre öğrencilere geçme notları verilmiştir. Bunun uygulamanın yanı sıra öğrencilerin devamlılık durumları ve atölye içinde gösterdikleri performans oranları incelenerek; geçme notları ile arasındaki ilişki araştırılmıştır. Elde edinilen veriler öğrencilerin devamlılık oranının \%100 ile \%65 arasında değişkenlik gösterirken, atölye performansını \%100 ile \%21 arasında değişkenlik gösterdiği gözlenmiştir. Buna veriler incelendiğinde; bazı öğrencilerin yaz okulu kapsamında öğrencilerin devam yüzdelerinin yüksek olmasına rağmen, atölye içinde ders yürütücülerinden kritik almadığı tespit edilmiştir. Öğrencilerin geçme notları ile performans yüzdeleri incelendiğinde elde edinilen veriler yüksek performansa sahip öğrencilerin yüksek geçme notuna, düşük performansa sahip öğrencilerin ise düşük geçme notuna sahip olduğunu göstermektedir. Stüdyo eğitiminde sonuç ürünün yanı sıra tasarım sürecinde ve atölye performansı olarak nitelendiren süreyi etkin kullanma oldukça önemlidir. Bu tasarım sürecini başarılı bir şekilde yönetebilen öğrenciler eğitim sonunda başarılı olurken, yönetemeyen öğrencilerin projelerinde pek çok aksaklıklar görüldüğü gözlemlenmiştir.

Sonuç olarak yaz okulu deneyiminin tartışıldığı bu çalışmada, yaz okulunun sınırıııkları, önemi, öğrenci ve yürütücüler tarafından yaşanan sorunlar ve geliştirilen çözüm önerileri ile yaz okulunun katkıları tartışılmaya çalışılmıştır. Kısıtlı sürede gerçekleştirilen bu deneyim ile öğrenciler öğrenim gördükleri eğitimden farklı üniversitelerin ve ders yürütücülerinin eğitim modellerini öğrenmişlerdir. Aynı zamanda atölye ortamında 7 farklı üniversiteden katılan öğrenciler ile çalışma imkanı bulmuşlar ve birbirlerinden tasarım programları öğrenmişlerdir. Öğrenciler yalnızca başarısız oldukları stüdyo derslerini dönem kaybı yaşamadan telafi etme şansı yakalamakla kalmayıp, aynı zamanda yaşadıkları şehirlerin dışında Konya ve Sille tarihi dokusunu görme, inceleme, analiz etme ve proje tasarımı yapma fırsatı yakalamışlardır. Öğrencilerin çoğunun şimdiye kadar yalnızca düz arazi yapısına sahip proje alanında tasarım yapmış olmaları ve eğimli arazide çalışmamış olması büyük bir kayıptır. Bu nedenle seçilen proje alanının eğimli olması nedeni ile öğrenciler farklı arazi yapısına sahip bir yerleşimde tasarım yapmışlardır. Yaz okulunun çok sayıda sınılılıklarının olması ve problemler yaşanmasının yanı sıra hem öğrenciler hem de yürütücüler açısından katkıları oldukça önemlidir.

\section{KAYNAKLAR}

Arıdağ, L. (2005). Mimari Tasarım Stüdyo Eğitiminde İletişim. (Yayınlanmamış Doktora Tezi), İstanbul Teknik Üniversitesi, İstanbul.

Boyer, E. L. ve Mitgang, L. D. (1996). Building community: A New Future for Architectural Education and Practice: A Special Report. Princeton: The Carnegie Foundation for the Advancement of Teaching.

Ciravoğlu, A. (2003). Mimari Tasarım Eğitiminde Formel ve Enformel Çalışmalar Üzerine. Yapı Dergisi(257), 43-47.

Demirel, Ö. (1999). Planlamadan Değerlendirmeye Öğretme Sanatı. Ankara: Pagem A Yayıncılık. 
Dikmen, Ç. B. (2011). Mimarlık Eğitiminde Stüdyo Çalışmalarının Önemi: Temel Eğitim Stüdyoları (Importance of the Studio Courses In Architectural Education: Basic Design Studios). e-Journal of New World Sciences Academy, 6(4), 1509-1520.

Dutton, T. A. (1987). Design and Studio Pedagogy. Journal of Architectural Education, 41(1), 16-25.

Düzgün, E. (2004). Mimari Tasarım Eğitiminde "Başarı Yönelimi"nin Ölçülmesi. (Yayınlanmamış Doktora Tezi), Yıldız Teknik Üniversitesi, İstanbul, Türkiye.

Hacıhasanoğlu, O., Hacıhasanoğlu, I. ve Erem, Ö. (2003). Tasarım Stüdyosundaki Amaçlar. Ege Mimarlık, 3(47), 29-31.

Ketizmen, G. (2002). Mimari Tasarım Stüdyosunun Biçimlenmesinde Yöntemsel ve Mekansal Etkilerin Incelenmesi: Anadolu Üniversitesi Mimarlık Bölümü Mimari Tasarım Stüdyosu Örneği. (Yayınlanmamış Yüksek Lisans Tezi), Anadolu Üniversitesi, İstanbul.

Ketizmen, G. (2003). Mimari Tasarım Stüdyosunda Çalışma Yöntemleri: Anadolu Üniversitesi Mimarlık Bölümü Örneği. Ege Mimarlık, 3(47), 32-34.

Konyalı, İ. H. (1964). Abideleri ve Kitabeleri ile Konya Tarihi. İstanbul: Yeni Basım Kitapevi.

Melikeoğlu Eke, A. S. ve Usta, G. (2016). The first year of design education: Abstract concrete problemcentered model. Global Journal of Arts Education, 6(1), 11-19.

Nalçakan, H. (2006). Küreselleşen Dünyada Mimarlık Eğitimi ve Türkiye. (Yayınlanmamış Yüksek Lisans Tezi), Yıldız Teknik Üniversitesi, İstanbul.

Oh, Y., Ishizaki, S., Gross, M. D. ve Do, E. Y.-L. (2013). A theoretical framework of design critiquing in architecture studios. Design Studies, 34(3), 302-325.

Onur, D. ve Zorlu, T. (2017). Tasarım Stüdyolarında Uygulanan Eğitim Metotları ve Yaratıcılık İlişkisi (The Relation Between The Training Methods Applied in Design Studios and The Creativity). The Turkish Online Journal of Design, Art and Communication, 7(4), 542-555.

Özer, B. (1964). Walter Gropius ve Mimarın Eğitimi Meselesi. Mimarlık Dergisi, 10(4), 5-6.

Rittel, H. (1985). Tasarım Eğitiminin Tasarımına İlişkin Bazı İlkeler. Mimarlık, 85(8), $20-22$.

Sachs, A. (1999). 'Stuckness' in the design studio. Design Studies, 20(195-209).

Schön, D. (1988). Designing: Rules, Types and Worlds. Design Studies, 9(3), 181-190.

Şahin, A. (2013). Mimarlık Eğitiminde Bir Stüdyo Yöntemi: Tasarla-Yap Stüdyosu. (Yayınlanmamış Yüksek Lisans Tezi), İstanbul Teknik Üniversitesi, İstanbul.

Tok, A. ve Ayyıldız Potur, A. (2016). Tasarım Stüdyolarında Eleştiri: Aktörler, Ortam, Kanallar Üzerine (Criticism in Design Studio: The Actors, Atmosphere, and Channels). Megaron, $11(3), 412-422$

Uluoğlu, B. (1990). Mimari Tasarım Eğitimi Tasarım Bilgisi Bağlamında Stüdyo Eleştirileri. (Yayınlanmamış Doktora Tezi), İstanbul Teknik Üniversites,, İstanbul.

Uluoğlu, B. (2000). Design knowledge communicated in studio critiques. Design Studies, 21(1), 33-58.

Yürekli, K. F. (2014). Mimarlık ve Eğitimi: "Firmitas, Utilitas, Venustas" ile Sürekli Savaşım. Arredamento Mimarlık, 2014(11), 107-111.

\section{EXTENDED ABSTRACT}

The main aim of the architectural education, which is different from the education of all other professions and where various design tools and methods are used, is to teach the design process. In addition to theoretical education such as thinking and interpreting architectural education in which various schools have emerged over time, there is a structure in which applied education is involved, including the process of designing and experiencing. Architectural studio courses are the most important cases that transfer the design process to the student and prepare the student for the profession and enable the student to develop 
design with various critics receives from the supervisor. Dutton (1987); It argues that it is the heart of architectural education for the design studio because it develops the ability to integrate other courses according to the curriculum and understand the architectural project. Targeted in architectural design studio; not to transfer design knowledge directly, but to enable the student to discover the information by placing the information in a context. Design knowledge can only be sustained if it is won in this way and can be adapted to future situations (Şahin, 2013).

Because of these difficulties of architectural design education, design is not a linear process starting with analysis and ending with synthesis, it is accepted as a circular progressive problem-solving process which progresses with continuous feedback (Rittel, 1985). In this study, the experience of summer school in a limited time period was evaluated in architectural design education where the process is very important. In this study, which aims to determine the process, limitations and differences of the summer school period, the continuity of the students in the studio education process, the critical take-up rates of the studio executives, the performance and final deliveries of the process were examined. In the present study, a workshop was held with two project teachers from the Department of Building Information and Restoration at two different instructors in collaboration with the students of architecture studio 5 and 6 , which were carried out simultaneously in the scope of the joint project area and needs program. Although architectural design education is 14 weeks / 112 hours in normal period, the process is 7 weeks in summer school. For this reason, two hours a week, 8 hours of lessons were made, and a total of 112 hours were taught. Thus, the period of the summer school and summer school period were synchronized with each other. Within the scope of the study, 21 students from 7 different universities (Bolu Abant İzzet Baysal University, Çukurova University, Dicle University, Düzce University, Erciyes University, Karabük University and Van Yüzüncü Yıl University) participated in the studio education within the scope of the summer school.

The project process has been programmed differently considering the adaptation status of a new university to the education system of architecture students who continue their education in different universities. In this context, it was emphasized that the students were different from the projects they worked before and the project area and the subject were determined by the instructors. When programming the summer school process, considering the limitations, the first two weeks, presentations were made by the instructors. using the theoretical knowledge transfer method in order to provide the adaptation process to the Selcuk University Department of Architecture education model and to establish the harmony with the instructors. In order to create an interactive classroom environment with the students and to be able to easily solve the problems encountered during the project, students were asked to make research in the studio environment by using case study method.

As the students did not recognize the project area, technical visits were made with the executives and the built environment, natural environment, pedestrian and vehicle transportation analyzes of the existing area were made during the trip with the students. After the first two weeks, students' criticisms of the project were given by using table criticism method. Two open jury and one final exam were conducted. In order to achieve statistical data during the seven-week period, the absences and the percentages of the critical acquisition were recorded in the flowchart. Project progress, in-class practices and project outcomes were examined in order to determine whether the targets were reached within the specified period. As a result, the data obtained from the study was evaluated to determine whether there is a linear relationship between the attendance rates of students and their critical take-up rates and project outputs and project passing grades.

When the obtained data is examined; While the attendance rate of the students varied between $100 \%$ and $65 \%$, it was observed that the workshop performance varied between $100 \%$ and $21 \%$. According to this; Although some students have high attendance percentages in the summer school, it has been determined that the students do not take the courses as critical. When the students' passing grades and performance percentages are examined, the data obtained shows that high performance students have high pass grades and low performance students have low pass grades. Efficient use of the term product in studio design as well as in the design process and workshop performance is very important. 
The students who can successfully manage this design process have succeeded at the end of the training, however, many failures have been observed in the students' projects.

In conclusion, this study discusses the summer school experience and discusses the limitations of the summer school, the problems experienced by the students and the instructors, the suggestions of the solutions developed and the contributions of the summer school. Through this experience, students learned the models of education of different universities and instructors. At the same time, they had the opportunity to work with students from 7 different universities and learned design programs from each other. The students not only had the chance to make up for the studio lessons they had failed, but also had the opportunity to see, analyze and design the Konya and the historical fabric of Sille outside of the cities they live in. The fact that most of the students have designed so far only in the project area with a flat land structure and not working on sloping land is a great loss. For this reason, the students have designed a settlement with a different land structure due to the inclination of the selected project area. In addition to having many limitations and problems in the summer school, the contributions of both the students and the instructors are very important. 